\title{
Comparative study of scientific publications in Ophthalmology and Visual Sciences in Argentina, Brazil, Chile, Paraguay and Uruguay (1995-2004)
}

\author{
Publicaciones científicas en oftalmología y visión: estudiocomparativo Argentina, \\ Brasil, Chile, Paraguay y Uruguay (1995-2004)
}

\author{
Carla P. Rag'ghianti ${ }^{1}$ \\ Rosa Martínez ${ }^{2}$ \\ Jorge Martins ${ }^{3}$ \\ Juan E. Gallo ${ }^{4}$
}

\begin{abstract}
\begin{tabular}{l} 
ABSTRACT \\
\hline Purpose: The study aimed to measure the scientific production in \\
Ophthalmology and Vision (O\&V) in Argentina, Brazil, Chile, Paraguay \\
and Uruguay over a period of 10 years (1995-2004), in order to find out \\
temporal evolution and variations in this field of research. Methods: \\
PubMed / Medline was used to retrieve records on O\&V research \\
literature. The search strategy included keywords, country in the affilia- \\
tion field and publication date. Data were extracted fromeach citation and \\
recorded in a spreadsheet. Subsequent analysis focused on type and \\
main topic of publication, journals where articles had been published, \\
and evolution of research done on animals and humans. Results: A total \\
of 1,216 citations were retrieved. Brazil had the largest number of \\
authored publications with an average annual production of 82.4 , followed \\
by Argentina with 31.0, Chile 6.4, Uruguay 1.6, and Paraguay 0.2. The ratio \\
of articles on O\&V relative to publications involving Health Science \\
ranged from 1.0 to 2.3. The frequency of publications almost tripled from \\
1995 to 2004. Research on humans showed a significant increase in \\
Argentina and Brazil. Conclusions: Results provide initial benchmarks \\
on O\&V publication rates in countries in South America that may be \\
useful to follow research trends.
\end{tabular}
\end{abstract}
Keywords: Bibliometrics; Research; Comparative study; Ophthalmology; South America

\footnotetext{
${ }^{1}$ Master en Información y Documentación. Licenciada en Bibliotecología y Documentación. Bibliotecaria de la Facultad de Ciencias Biomédicas de la Universidad Austral - Buenos Aires - Argentina.

${ }^{2}$ Licenciada en Bibliotecología y Documentación. Bibliotecaria de Alcon Laboratorios Argentina - Buenos Aires - Argentina.

${ }^{3}$ Licenciado en Psicología. Bibliotecario del Consejo Argentino de Oftalmología - Buenos Aires - Argentina. ${ }^{4}$ Médico, Doctor en Medicina. Profesor de Oftalmología de la Facultad de Ciencias Biomédicas de la Universidad Austral - Buenos Aires - Argentina.

Author address: Juan E. Gallo. Universidad Austral Departamento de Oftalmología. Av. Pte. Perón, 1500 1629 Pilar - Buenos Aires - Argentina.

E-mail: jgallo@cas.austral.edu.ar

Recebido para publicação em 09.11.2005

Última revisão recebida em 14.12.2005 Aprovação em 07.02.2006

Nota Editorial: Depois de concluída a análise do artigo sob sigilo editorial e com a anuência do Dr. Wilmar Roberto Silvino sobre a divulgação de seu nome como revisor, agradecemos sua participação neste processo.
}

\begin{abstract}
Ceywords: Bibliometics; Research; Comparative study; Ophthalmology; South America
\end{abstract}
\section{INTRODUCTION}

The study of scientific publications in a particular field, based on international bibliographic data, is one of the widely used methods to measure scientific achievement ${ }^{(1-2)}$. It is well documented that the European Union and the United States are the leading powers in biomedical investigation and publications ${ }^{(3-4)}$. Few studies obtaining indicators of scientific production in Ophthalmology and Visual Sciences (O\&V) have been conducted. Some of them included an analysis of articles published during a specific period in journals with a high impact factor relevant to $O \& \mathrm{~V}^{(5-7)}$. Others identified peer-reviewed publications by national authors to reveal the contribution of a country to $\mathrm{O} \& \mathrm{~V}$ literature ${ }^{(8-9)}$. However, these previous studies did not mention the countries included in our investigation. In order to obtain a macroview of research output in South American countries, a bibliometric analysis was performed. Although any database may be a source for conducting quantitative studies of information ${ }^{(10)}$, this study 
was based on Medline / PubMed. This is the most commonly consulted database specialized in Health Science in Argentina. Medline /PubMed is useful to analyze the internationally most visible scientific production since it covers biomedical journals satisfactorily and it is freely available in the Internet. Furthermore, journals seeking to be indexed by this database are evaluated according to their coverage, content quality, editorial work and other critical aspects by the Literature Selection Technical Review Committee ${ }^{(11)}$.

The aim of this study was to measure and analyze the scientific production in the field of $\mathrm{O} \& \mathrm{~V}$ in Argentina, Brazil, Chile, Paraguay and Uruguay over a period of 10 years (1995-2004), and calculate geographical and yearly evolution, variations and trends in this field of research. To the best of our knowledge, this type of study has not previously been published.

\section{METHODS}

Scientific publications from Argentina, Brazil, Chile, Paraguay and Uruguay were identified by searching the PubMed / Medline database. The bibliographic search strategy used was: Keywords AND Country AND Publication Date (see table 1 for further details). The following data were obtained from each citation and recorded in a spreadsheet: publication date, affiliation, author, language, publication type, place of publication, journal title, Medical Subject Headings (MeSH) Major Topic. It was necessary to manually identify and exclude those citations not related to $\mathrm{O} \& \mathrm{~V}$.

To examine the productivity of the institution where the

\section{Table 1. Criteria used for the bibliographic search}

\begin{tabular}{|c|c|}
\hline $\begin{array}{l}\text { Keywords } \\
\text { MESH Major Topics } \\
\text { with the feature Explode } \\
\text { active in all of them but } \\
\text { Ophthalmic Surgical } \\
\text { Procedures }\end{array}$ & $\begin{array}{l}\text { Contact Lenses OR Diagnostic } \\
\text { Techniques, Ophthalmological OR } \\
\text { Eye OR Eye Diseases OR Eye } \\
\text { Injuries OR Lenses, Intraocular OR } \\
\text { Ocular Motility Disorders OR Ocular } \\
\text { Physiology OR Ophthalmologic } \\
\text { Surgical Procedures OR Ophthalmo- } \\
\text { logy OR Orbit OR Orthoptics OR } \\
\text { Vision Disorders }\end{array}$ \\
\hline $\begin{array}{l}\text { Name of the country } \\
\text { in the affiliation field } \\
\text { (variations in the spelling } \\
\text { were considered) }\end{array}$ & $\begin{array}{l}\text { Argentina OR Argentine } \\
\text { Brazil OR Brasil } \\
\text { Chile } \\
\text { Uruguay } \\
\text { Paraguay }\end{array}$ \\
\hline Publication date & from 1995 to 2004 \\
\hline
\end{tabular}

research had been carried out, data were derived from the Affiliation Field and classified into one of these categories: Universities, Hospital and Others (Foundations, Pharmaceutical Companies, Professional Associations, etc.). University Hospitals were included in the Hospital category.

An analysis of the subject areas was made grouping the MeSH Major Topics of each article in the following categories and their frequency calculated: Lacrimal Apparatus; CorneaConjunctiva; Crystalline Lens-Cataract; Sclera; Glaucoma; Diagnostic Techniques, Ophthalmological; Oculomotor Muscles; Neuro-ophthalmology; Eye-Systemic Diseases; EyelidsOrbit; Ocular Refraction-Ocular Refraction Surgery; RetinaVitreous Body; Uvea.

Another issue of interest was the analysis of the research performed on animals in Brazil and Argentina. Records that were coded with the MESH Term "Animals" and "Human" were compared.

\section{RESULTS}

The total number of identified articles on O\&V in the five countries over the 10 -year period was 1216 . Table 2 shows data regarding the geographical distribution of articles published on Health Science and O\&V. The ratio of O\&V papers to the total number of medical papers is also shown. Brazil has the largest number of authored papers with an annual average production of 82.4, followed by Argentina with 31.0, Chile with 6.4, Uruguay with 1.6 and Paraguay with 0.2.

Regarding the trend over the decade under study (Figure 1),

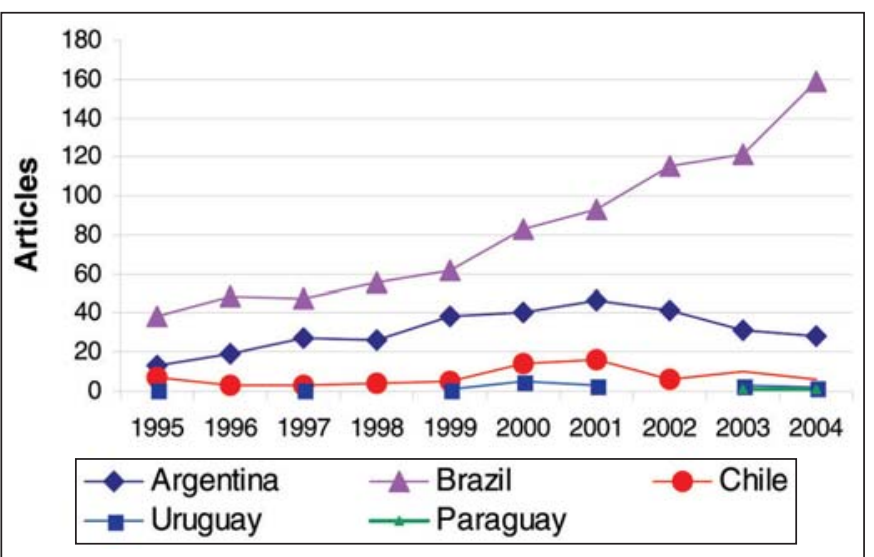

Figure 1 - Scientific publication trend in O\&V, 1995-2004

\begin{tabular}{|c|c|c|c|c|c|c|}
\hline & Argentina & Brazil & Chile & Paraguay & Uruguay & Total \\
\hline Articles in HS (\%) & $14310(23 \%)$ & $40702(65 \%)$ & $6080(10 \%)$ & $79(0 \%)$ & $1104(2 \%)$ & $62275(100 \%)$ \\
\hline Articles in O\&V (\%) & $310(25 \%)$ & $824(68 \%)$ & $64(5 \%)$ & $2(0.2 \%)$ & $16(1 \%)$ & $1216(100 \%)$ \\
\hline $\begin{array}{l}\text { Ratio of articles in O\&V } \\
\text { relative to publications in HS }\end{array}$ & 2.3 & 2.0 & 1.0 & 2.5 & 1.4 & 1.9 \\
\hline
\end{tabular}


Brazil has steadily increased the number of publications, with a fourfold rise between 1995 and 2004. The growth experienced by Argentina reached its peak in 2001. From that year up to 2004, in contrast with Brazil, there has been a continuous decrease, which enlarged the gap between the two countries. Anyhow, in 2004, Argentina doubled the number of articles published in 1995. Chile and Uruguay have a similar pattern, with fluctuations along the 10-year period, but showing no or little increase at the end. Paraguay has its first publication in 2003 and a second one in 2004.

Considering the five countries, the articles were published in 5 different languages. More than three-quarters of the publications were published in English (93.2\%). Spanish (4.1\%) was the second most common language followed by Portuguese $(2.5 \%)$ and others $(0.2 \%)$ (one article in French and one in German). In Argentina, Brazil, Paraguay and Uruguay the articles written in English exceeded $90 \%$ while in Chile articles in Spanish increased their presence (Figure 2).

According to the type of publication and considering the total number of articles, Original Article was the most common category reaching $66.9 \%$. It was followed by Case Reports $21 \%$, Clinical Trials $6.3 \%$, Review $4.5 \%$ and others (e.g. Validation Studies, Historical Article) $1.7 \%$.

The largest number of contributions came from Universities, followed by Hospitals in all countries but in Argentina, where the distribution of papers is more equitable between the different types of institutions (Figure 3). The 1216 articles were published in 360 different journals. The number of articles published per journal varied widely. Table 3 shows the journals in which more papers were published in the five countries.

Figure 4 shows the evolution of animal and human research in Argentina and Brazil. In both countries, there was an important increase in clinical research.

According to the subject areas, the main topic of the articles on $\mathrm{O} \& \mathrm{~V}$ from these countries was Retina-Vitreous Body (26.9\%), followed by Eye-Systemic Diseases (19.5\%), CorneaConjunctiva (12.0\%), Neuro-ophthalmology (7.9\%), Eyelids-
Orbit (6.7\%), Refraction-Ocular Refraction Surgery (6.2\%) and in the remaining $(20.7 \%)$ distributed among the other areas.

\section{DISCUSSION}

The present study contributes to the knowledge of scientific publications on O\&V in Argentina, Brazil, Chile, Paraguay and Uruguay. We have measured and analyzed the scientific production of those countries over a period of ten years (1995-

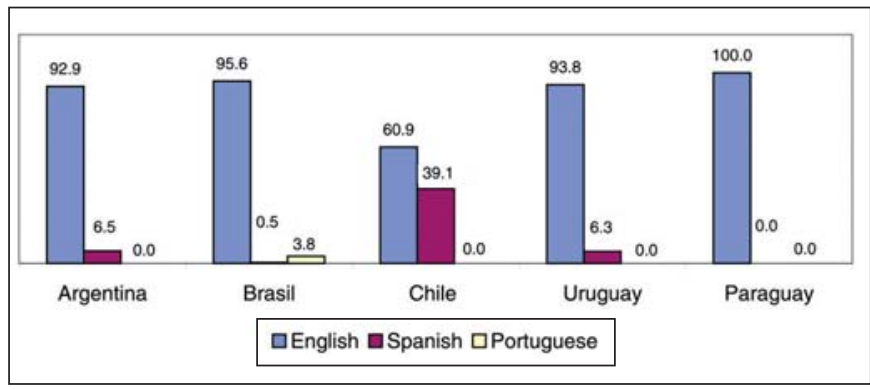

Figure 2 - Language of articles according to the country

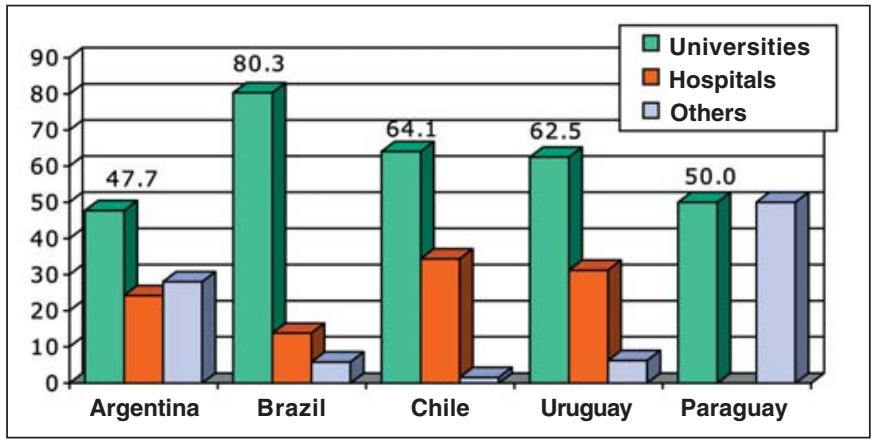

Figure 3 - Productivity of the institution where research had been carried out
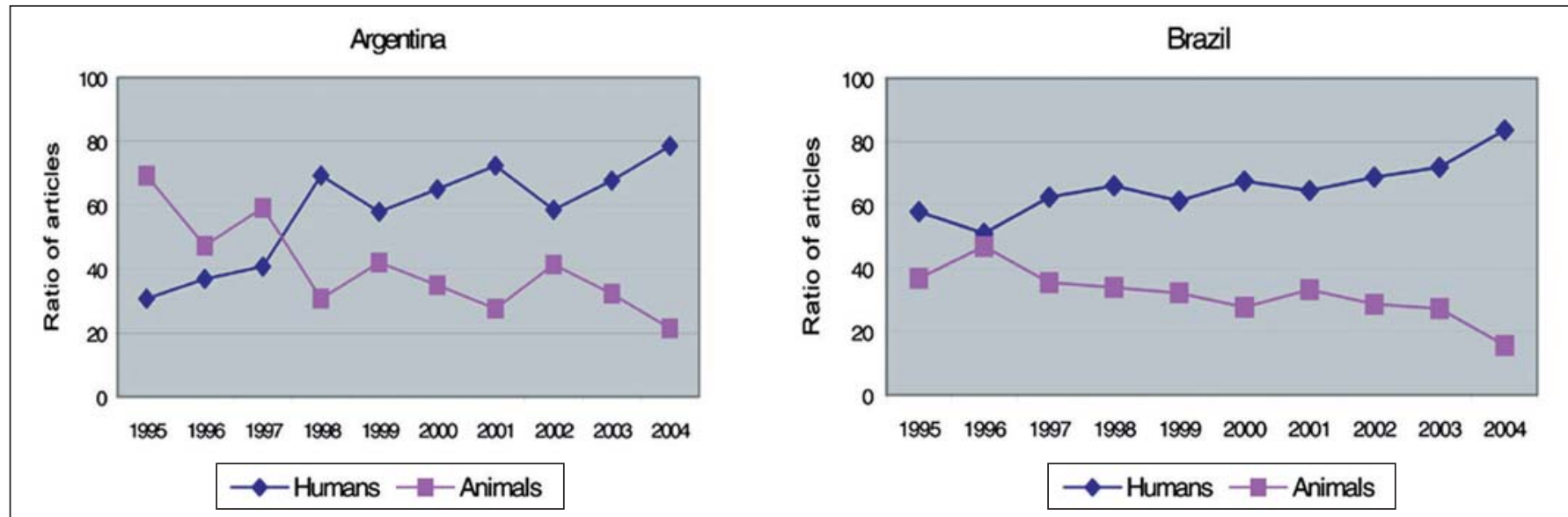

Figure 4 - Comparison between animal and human research in Argentina and Brazil 
2004) and determined the temporal evolution, variations and trends in the field of research.

Nevertheless, these results should be considered with caution, taking into account some inherent limitations. This bibliometric study was based only on the Medline / PubMed database where many nationals journals written in languages other than English are not indexed. In order to do a more exhaustive research on $\mathrm{O} \& \mathrm{~V}$ in Latin American countries, the use of other database such as LILACS (Literatura Latinoamericana y del Caribe en Ciencias de la Salud) is required. Another drawback of Medline / PubMed is that it includes only affiliation details of the first author. In this study the affiliation field was used to retrieve records by country, i.e. the scientific production, in this case, is associated with institutions rather than with authors. A paper was attributed to a country if the

\begin{tabular}{|lc|}
\hline \multicolumn{2}{|c|}{$\begin{array}{c}\text { Table 3. Journals that published more articles from the countries } \\
\text { covered by the study on O\&V }\end{array}$} \\
Journals & Number of articles \\
Argentina & 23 \\
J Cataract Refract Surg & 13 \\
J Refract Surg & 12 \\
J Neurochem & 11 \\
Int Ophthalmol & 10 \\
Invest Ophthalmol Vis Sci & 8 \\
Medicina (B Aires) & 7 \\
Neurochem Res & 6 \\
J Neurosci Res & 5 \\
Exp Eye Res & 5 \\
Binocul Vis Strabismus Q & \\
Brazil & 50 \\
Braz J Med Biol Res & 46 \\
Arq Neuropsiquiatr & 28 \\
Am J Ophthalmol & 27 \\
Ophthal Plast Reconstr Surg & 23 \\
J Cataract Refract Surg & 23 \\
Ophthalmology & 22 \\
J Refract Surg & 20 \\
Cornea & 17 \\
Br J Ophthalmol & 16 \\
Brain Res & 21 \\
Chile & 2 \\
Rev Med Chil & 2 \\
Arthritis Rheum & 2 \\
Biol Res & 2 \\
Invest Ophthalmol Vis Sci & 2 \\
J AAPOS & 2 \\
Uruguay & 2 \\
Acta Otolaryngol & 2 \\
Exp Eye Res & 2 \\
Cell Tissue Res & \\
Biochem Biophys Res Commun & 2 \\
Paraguay & 2 \\
Graefes Arch Clin Exp Ophthalmol & \\
Ophthalmic Epidemiol & \\
\hline & \\
\hline
\end{tabular}

first author provided an address in that country. So, articles by authors of the countries covered in the study are excluded when, for whatever reasons, they appear with an affiliation different from their own country. Despite these shortcomings, Medline / PubMed includes a highly efficient hierarchical thesaurus and provides the explode and focus functions ${ }^{(12)}$. The use of these two searching methods ensures the reliability of the search carried out in this study ${ }^{(12)}$.

The results of our study shows that the number of articles on O\&V credited to institutional authors in Argentina, Brazil, Chile, Paraguay and Uruguay, and published in international journals almost tripled from 1995 to 2004. These results agree with a Science Watch survey in which it is stated that Latin America is steadily increasing its presence on the world scientific stage ${ }^{(13)}$.

From 1995 to 2001, the increase in the number of articles is concentrated especially in Argentina and Brazil. But, from 2001 to 2004, the number of papers from Argentina declined whereas that from Brazil increased, widening the gap in scientific publications between Brazil and the rest of the countries. Brazil experienced a clear upward trend in scientific publications on health disciplines as a whole and now is listed nineteenth in a ranking of the top 20 health-related publication producers in the world $^{(14)}$. The ratio of O\&V to the total number of medical papers is quite similar among the countries, running from $1.0 \%$ to $2.5 \%$. It is worth noting that nations such as Germany, Australia and the United Kingdom, ranked among the top 20 nations contributing to world ophthalmology research, have a ratio of $\mathrm{O} \& \mathrm{~V}$ articles varying from $3.3 \%$ to $3.7 \%$ in relation to publications concerning Health and Science ${ }^{(15)}$.

The most used language was English. The lesser use of Spanish and Portuguese, the mother tongues of the countries covered in this study, may be related to the accepted fact that publishing in English increases diffusion and visibility ${ }^{(1)}$. It is more difficult for an article published in Spanish or Portuguese to be read by researchers from other parts of the world. Some Latin American Health Science journals seem to take this viewpoint, and have chosen English as the second language for the publication of their articles. In order to gain visibility and bridge geographical boundaries, we suggest that the electronic format of a journal might well give the option of reading the full text of an article in at least two languages. Nevertheless, in Chile there is a high percent of articles in Spanish, showing a preferential submission to their own language and national journals.

The analysis of the publication type field of the records shows a low rate of clinical trials on $\mathrm{O} \& \mathrm{~V}$ in the five countries, although they are currently considered as a method of choice to prove the validity of a health care intervention ${ }^{(16)}$. These results match up with the fact that Latin America registered a total number of clinical trial reports similar to that found in Finland as a country ${ }^{(16)}$.

The most productive institution sector were Universities; however, in Argentina private associations and foundations played a more important role in research compared to the other countries. 
Argentinean and Brazilian institutions published their articles in a wide range of journals. Medicina de Buenos Aires, which accepts articles devoted to different aspects of clinical or experimental medicine, is among the ten journals to which Argentinean institutions submitted more articles. Not only is this journal indexed in Medline, but it also publishes original articles and short communications submitted in English or Spanish. This is an alternative way for researchers to join the scientific international community through a national journal. It should be stressed that Argentina has had a specialized journal in ophthalmology since 1925. It is called Archivos de Oftalmología de Buenos Aires and is published by the Sociedad Argentina de Oftalmología, and was indexed in Medline from 1965 to 1971. In Brazil, the Brazilian Journal of Medical and Biological Research and Arquivos de Neuro-psiquatria were found to be the most chosen journals to publish articles on $\mathrm{O} \& \mathrm{~V}$ research in the period covered by the study. This country, up to 1971, had two specialized journals in ophthalmology indexed in Medline. Over the ten studied years, none of them was included in the database. Yet, from January 2005, the Arquivos Brasileiros de Oftalmologia has been incorporated again in the list of journals indexed by this prestigious database, thus increasing its articles' visibility ${ }^{(17)}$. As it was mentioned above, in Chile there was a large submission of articles on $\mathrm{O} \& \mathrm{~V}$ in the national journal Revista Médica de Chile.

The study also shows that there is considerable disparity in the evolution of animal or human research in Argentina and Brazil. In both countries research on humans increased steadily, Argentina shows a greater significant reduction in animal research, though. The majority of studies in Argentina and Brazil deal with Retina-Vitreous Body.

The present study is the first to provide some initial benchmarks on O\&V research trends in Argentina, Brazil, Chile, Uruguay and Paraguay from which changes can be charted in the future. We believe that this approach provides useful information to discover a new perspective of $O \& V$ in South America. Nevertheless, more work needs to be done in order to examine valid measures of $\mathrm{O} \& \mathrm{~V}$ research quality and quantity in these countries.

\section{RESUMEN}

Objectivo: Cuantificar y analizar las publicaciones científicas en Oftalmología y Ciencias de la Visión (O\&V) de Argentina, Brasil, Chile, Paraguay y Uruguay, en un período de 10 años (1995-2004) para conocer la evolución y tendencias en este campo de investigación. Métodos: Se utilizó la base de datos PubMed / Medline para identificar las publicaciones científicas en $O \& V$. En la estrategia de búsqueda se utilizaron palabras claves relacionadas a $\mathrm{O} \& \mathrm{~V}$, nombre de los países en el campo de afiliación y fecha de publicación. Se procesaron los datos con una planilla de cálculo para analizar el idioma y tipo de artículo, el tema de la investigación y la evolución de los trabajos realizados en animales y en personas. Resultados: Los cinco países han publicado un total de 1216 artículos en revistas indexadas en Medline. Brasil presenta la mayor cantidad de trabajos científicos publicados, con un porcentaje de producción anual de 82.4, seguido por Argentina con 31,0, Chile 6.4, Uruguay 1.6 y Paraguay 0.2. El porcentaje de artículos en O\&V en relación con las Ciencias Biomédicas presenta un rango de 1.0 a 2.3. De 1995 al 2004, la suma de publicaciones de estos países se incrementa aproximadamente en tres veces. La investigación en humanos presenta un aumento significativo en Argentina y en Brasil. Conclusiones: Los resultados del estudio proporcionan datos inéditos sobre la investigación en $\mathrm{O} \& \mathrm{~V}$ en países de América del Sur que podrían ser tomados como referencia para hacer un futuro seguimiento de las tendencias en la producción científica.

Descriptores: Bibliometría; Investigación; Estudio comparativ; Oftalmología; América del Sur

\section{REFERENCES}

1. Sanchez-Carbonell X, Guardiola E, Belles A, Beranuy M. European Union scientific production on alcohol and drug misuse (1976-2000). Addiction. 2005;100(8):1166-74.

2. Fernández R. Análisis bibliométrico de la producción científica. Ciencia Hoy [serial on the Internet]. 1998 [cited: 2005 Sept 11]; 8(44):[about 9 p.] Available from: http://www.ciencia-hoy.retina.ar/hoy44/biblio1.htm.

3. Soteriades ES, Falagas ME. Comparison of amount of biomedical research originating from the European Union and the United States. BMJ. 2005; 331(7510): 192-4

4. Philipson L. Medical research activities, funding, and creativity in Europe: comparison with research in the United States. JAMA. 2005;294(11):1394-8.

5. Rahman M, Sakamoto J, Fukui T. Japan's share of published research in ophthalmology. Jpn J Ophthalmol. 2003;47(2):221-4.

6. Ang A, Tong L, Bhan A. Analysis of publication trends in two internationally renowned ophthalmology journals. Br J Ophthalmol. 2001;85(12):1497-8.

7. Mandal K, Benson S, Fraser SG. The contribution to ophthalmic literature from different regions of the world. Int Ophthalmol. 2004;25(3):181-4.

8. Davis M, Wilson CS. Research contributions in ophthalmology: Australia's productivity. Clin Experiment Ophthalmol. 2003;31(4):286-93.

9. Pon JA, Carroll SC, McGhee CN. Analysis of New Zealand's research productivity in ophthalmology and vision science: 1993-2002. Clin Experiment Ophthalmol. 2004;32(6):607-13.

10. Sanz-Casado E, Suarez-Balseiro C, García-Zorita C, Martín-Moreno C, Lascurain-Sánchez ML. Metric studies of information: An approach towards a practical teaching method. Educ Inf. 2002;20(2):133-44.

11. United States National Library of Medicine. Journal selection for Medline fact sheet [text on the Internet]. Bethesda (MD): National Library of Medicine; 2005. [cited 2005 Jul 16]. Available from: http://www.nlm.nih.gov/pubs/ factsheets/jsel.html.

12. Gehanno JF, Thirion B. How to select publications on occupational health: the usefulness of Medline and the impact factor. Occup Environ Med. 2000; 57(10):706-9.

13. Latin America: a growing presence. Science Watch [serial on the Internet] 2001 [cited 2005 Sept 11];12(5):1-2. Available from: http://www.sciencewatch.com/sep-oct2001/sw_sep-oct2001_page1.htm.

14. Paraje G, Sadana R, Karam G. Public health. Increasing international gaps in health-related publications. Science. 2005;308(5724):959-60.

15. Moreno-Montañés J. Trabajos españoles publicados en las revistas de oftalmología. Arch Soc Esp Oftalmol. 2003;78(11):585.

16. Cañedo Andalia R, Arencibia RJ, Perezleo Solorzano L, Conill González C, Araújo Ruiz JA. La Colaboración Cochrane en Cuba: producción de ensayos clínicos en Iberoamérica. ACIMED [serial on the Internet]. 2003 [cited 2005 Aug 10]; 11(6): [about 19 p.]. Available from: http://scielo.sld.cu/scielo.php?script= sci_arttext\&pid=S1024-94352003000600004\&lng=es\&nrm=iso\&tlng=es.

17. Bicas HEA, Muccioli C, Goldchmit M, Campos MSQ, Dantas PEC, Bechara SJ, et al. Prestigiosa validação de nossos padrões editoriais. Arq Bras Oftalmol. 2005;68(1):5-6. 